Note

\section{Respiratory Deficient Mutation at Elevated Temperature in Saccha- romyces cerevisiae: Stimulatory Effect of Inorganic Salts}

\author{
Midori Yamamura and Teijiro Kamihara \\ Laboratory of Industrial Biochemistry, Department of \\ Industrial Chemistry, Faculty of Engineering. \\ Kyoto University, Kyoto 606, Japan
}

Received September 29, 1989
The effects of yeast extract were first examined since some constituents of yeast extract had been suggested to affect the petite frequency as mentioned above. The products of four of the five yeast extract makers tested gave the spontaneous levels of petite frequency $(<10 \%)$. In contrast, the great majority of cells grown at $40^{\circ} \mathrm{C}$ were petite mutants when the yeast extract preparations of a particular maker were used. The petite frequency was dependent on the product number of the maker. Instead of making efforts to extract and identify the active principle(s) in yeast extract, we investigated the effects of conventional substances. Addition of casamino acids to the growth medium caused a dose-dependent increase in petite frequency. Unexpectedly, however, an amino acid mixture which had the same composition with that of casamino acids showed no effect. $\mathrm{NaCl}$ was then examined

Table I. Effects of Various SALtS ON

In 1959, Sherman ${ }^{1)}$ reported that there was a great increase in the fraction of petite mutants in Saccharomyces cerevisiae when the cells were grown at elevated temperatures $\left(38\right.$ and $40^{\circ} \mathrm{C}$ ) in a complex medium containing $6 \%$ yeast extract which permitted the yeast to grow at the supraoptimal temperatures. ${ }^{2)}$ We have found, however, that the petite mutation frequency was less than $10 \%$ under the same conditions in cultures of $S$. cerevisiae ATCC 7753 and other mesophilic yeasts except for a thermotolerant isolate of $S$. cerevisiae. ${ }^{3)}$ The petite frequency $(<10 \%)$ was the same as that attained spontaneously at ordinary temperatures $\left(30^{\circ} \mathrm{C}\right.$ or so) in complex media. This discrepancy between our results and those of Sherman suggests that petite mutation at elevated temperatures depends on yeast strains and/or the constituents of the yeast extracts used.

The mechanism of petite mutation at elevated temperature may be quite different from that of the mutations caused by UV, X-ray, or chemical mutagens such as acriflavin and ethidium bromide. The spontaneous petite mutation mentioned above would be stimulated by the rise of temperature. The mechanism of the spontaneous petite mutation has been essentially clarified at the molecular level of mitochondrial DNA (mtDNA), ${ }^{4}$ but little is known about the stability of mtDNA in intact mitochondria where miDNA is suggested to be bound to the inner membrane through some protein. ${ }^{5}$ Studies on the elevated temperature-induced petite mutations would pyrovide some useful information about the stability of mtDNA, since the fluidity and related properties of the inner membrane should be affected by temperature.

Before exploring the relationship between the stability of mtDNA and of the membrane, it is necessary to establish the culture conditions to control the petite mutation frequency at elevated temperatures. This paper describes the effects of supplementary substances in the medium on petite mutation frequency during cultivation of an ordinary strain of $S$. cerevisiae at $40^{\circ} \mathrm{C}$. Petite Frequency

\begin{tabular}{|c|c|c|}
\hline Salt & $\begin{array}{l}\text { Concentration } \\
\text { (M) }\end{array}$ & $\begin{array}{c}\text { Petite frequency } \\
(\%)\end{array}$ \\
\hline None & & 3.9 \\
\hline \multirow{3}{*}{$\mathrm{NaCl}$} & 0.13 & 17.9 \\
\hline & 0.26 & 43.3 \\
\hline & 0.52 & 48.0 \\
\hline \multirow[t]{2}{*}{$\mathrm{KCl}$} & 0.13 & 65.7 \\
\hline & 0.52 & 68.9 \\
\hline \multirow[t]{3}{*}{$\mathrm{MgCl}_{2}$} & 0.065 & 20.2 \\
\hline & 0.13 & 34.4 \\
\hline & 0.26 & 40.6 \\
\hline \multirow[t]{2}{*}{$\mathrm{NH}_{4} \mathrm{Cl}$} & 0.13 & 1.0 \\
\hline & 0.52 & $2.5^{*}$ \\
\hline \multirow[t]{3}{*}{$\mathrm{NaNO}_{3}$} & 0.13 & $21.8^{*}$ \\
\hline & 0.26 & 22.8 \\
\hline & 0.52 & 32.7 \\
\hline \multirow[t]{2}{*}{$\mathrm{Na}_{2} \mathrm{SO}_{4}$} & 0.13 & 54.7 \\
\hline & 0.26 & 74.5 \\
\hline \multirow[t]{2}{*}{$\mathrm{K}_{2} \mathrm{SO}_{4}$} & 0.13 & 59.8 \\
\hline & 0.26 & $84.4^{*}$ \\
\hline \multirow[t]{2}{*}{$\mathrm{MgSO}_{4}$} & 0.13 & 47.5 \\
\hline & 0.26 & 58.4 \\
\hline$\left(\mathrm{NH}_{4}\right)_{2} \mathrm{SO}_{4}$ & 0.13 & 1.4 \\
\hline \multirow{2}{*}{$\mathrm{CH}_{3} \mathrm{COONa}$} & 0.13 & $6.3 *$ \\
\hline & 0.52 & $0.6^{*}$ \\
\hline
\end{tabular}

* Results of single experiments. Other data are the mean values of two to six experimental results. Cultivation of $S$. cerevisiae ATCC 7753 and estimation of petite frequency were done as described previously ${ }^{3)}$ except that only the medium YP Iglucose $4 \%$, yeast extract (Difco) $1 \%$, peptone (Difco) $1 \%$, and $\mathrm{KH}_{2} \mathrm{PO}_{4} 1 \%$ I was used for preculture, and the cells obtained were inoculated at a fixed size $\left(10^{5}\right.$ cells per $\mathrm{ml}$ ) onto medium $6 \mathrm{Y}$ [glucose $4 \%$, yeast extract (Difco) $6 \%, \mathrm{KH}_{2} \mathrm{PO}_{4} 0.5 \%$ which had been supplemented with the indicated salts. 
for the effect on petite frequency since casamino acids contain the salt at a high concentration of $38 \% . \mathrm{NaCl}$ actually had a stimulatory effect on petite frequency. However, the frequencies of petite mutation caused by various concentrations of $\mathrm{NaCl}$ were significantly lower than those by. equivalent concentrations of casamino acids. Addition of $\mathrm{NaCl}$ with the amino acid mixture resulted in an increase in the petite frequency, suggesting a synergistic effect of $\mathrm{NaCl}$ and amino acids.

Not only $\mathrm{NaCl}$, but also other inorganic salts tested except $\mathrm{NH}_{4}{ }^{+}$and $\mathrm{CH}_{3} \mathrm{COO}^{-}$salts stimulated petite formation, as shown in Table 1 . The effects of salts were compared in terms of chemical equivalents. The decreasing order of the effects of cations tested was as follows: $\mathrm{K}^{+}>\mathrm{Na}^{+}>\mathrm{Mg}^{2+} \gg \mathrm{NH}_{4}{ }^{+} . \mathrm{NH}_{4}{ }^{+}$, in contrast to the metal cations, decreased the petite frequency below those attained spontaneously. The counter anions also increased the petite frequency in the following order: $\mathrm{SO}_{4}{ }^{2-}>\mathrm{Cl}^{-}>\mathrm{NO}_{3}{ }^{-} \gg \mathrm{CH}_{3} \mathrm{COO}^{-}$. Petite frequency in the presence of added $\mathrm{CH}_{3} \mathrm{COO}^{-}$salts was below the spontaneous levels as in the case of $\mathrm{NH}_{4}{ }^{+}$. There were great differences in the effects of the ions tested, and the effects of metal cations and inorganic anions appear to be additive. Therefore, the ion-induced increase in petite frequency may not be purely due to ionic strength.

The results obtained in this paper clearly demonstrate that petite mutation of $S$. cerevisiae at elevated temperatures which was reported for the first time by Sherman ${ }^{11}$ is dependent largely on the medium composition, although the mechanism remains to be elucidated.

\section{References}

1) F. Sherman, J. Cell. Comp. Physiol., 54, 37 (1959).

2) F. Sherman, J. Cell. Comp. Physiol., 54, 29 (1959).

3) M. Yamamura, Y. Nagami, V. Vongsuvanlert, J. Kumnuanta and T. Kamihara, Can. J. Microbiol, 34, 1014 (1988).

4) G. Bernardi, in "DNA makes RNA makes Protein," ed. by T. Hunt, S. Prentis and I. Tooze, Elsevier Biomedical Press BV, Amsterdam, The Netherlands, 1983, pp. 67-84.

5) T. Kuroiwa, Kagaku (Science). 56, 339 (1986). 